\title{
Effect of internal curing on performance of self-compacting concrete by using sustainable materials
}

\author{
Nada Aljalawi ${ }^{1}$, and Amar Yahia AL-Awadi ${ }^{1}$ \\ ${ }^{1}$ Engineering College, University of Baghdad, Baghdad, Iraq
}

\begin{abstract}
This paper is devoted to investigate the effect of internal curing technique on the properties of self-compacting concrete. In this study, self-compacting concrete is produced by using limestone powder as partial replacement by weight of cement with percentage of $(5 \%)$, sand is partially replaced by volume with saturated fine lightweight aggregate which is thermostone aggregate as internal curing material in three percentages of $(5 \%, 10 \%, 15 \%)$ for self-compacting concrete, and the use of two external curing conditions which are water and air. The experimental work was divided into three parts: in the first part, the workability tests of fresh self-compacting concrete were conducted. The second part included conducting compressive strength test and modulus of rupture test at ages of (7,28 and 90) days. The third part included doing the shrinkage test at age of $(7,14,21,28)$ days. The results show that internally cured selfcompacting concrete has the best workability and the best properties of hardened concrete which include (compressive strength, modulus of rupture) of externally cured self-compacting concrete with both water and air as compared with reference concretes. Also, the hardened properties of internally cured selfcompacting concrete with percentage of $(5 \%)$ with thermostone aggregate is the best as compared with that of percentages $(10 \%$ and $15 \%)$ in both external curing conditions. In general, the results of shrinkage test have shown reduction in shrinkage of internally cured self-compacting concrete as compared with reference concretes and this reduction increases with increase in the thermostone aggregate content-within-selfcompacting-concrete.
\end{abstract}

\section{Introduction}

Self-compacting concrete (SCC) is a type of concrete that gets compacted under its self-weight. It is commonly abbreviated as SCC and defined as the concrete that is capable of self-compacting and occupying all the spaces in the formwork without any vibration; purely by means of its self-weight, thereby eliminating the need for either external energy input from vibrators or any type of compacting effort. The use of SCC is spreading worldwide because of its very attractive properties in the fresh state as well as after hardening. The use of SCC will lead to reduce the technical costs of in situ concrete constructions and eliminate some of the potential human error. It will replace manual compaction of fresh concrete with a modern semiautomatic placing technology and in that way,

improve health and safety in and around the construction site [22].

Term internal curing means "supplying water throughout a freshly placed cementitious mixture using reservoirs, via pre-wetted lightweight aggregates that readily release water as needed for hydration or to replace moisture lost through evaporation or self-desiccation" according to the definition provided in American Concrete Institute. Also, the hydration of cement continues because of the availability of internal water that is not part of the mixing water, refers to internal curing technique [1].

\section{Literature review}

The concept of SCC was first proposed by Professor Hajime Okamura, in 1986 in Japan as a 
solution to concrete's concerns. There are many advantages of using SCC, these include [7] [15]:

- Elimination of the need for vibration.

- Reducing the noise pollution.

- Improving the filling capacity of highly congested structural member.

- Reducing the construction time and labor cost.

Self-compacting concrete (SCC) is characterized by high resistance to segregation that can be cast without compaction or vibration. It flows like honey, de-aerates, self-compacts and has nearly a horizontal concrete level after placing [14]. Internal curing has been discussed as an added advantage in concrete research. It has wider prospect in many countries and it is possible to get benefit from the internal curing instead of traditional external curing. Internal curing has a significant contribution in shrinkage reduction. In the advancement of concrete technology internal curing is found to be beneficial in terms of enhancing concrete performance as well as environment friendly [20].

The main properties of lightweight aggregate (LWA) are its high porosity, high absorption, low specific gravity and cellular structure. These properties make LWA a suitable material for internal curing technique [19].

By replacing a portion of the normal weight aggregates with pre-wetted lightweight aggregates (LWA), additional internal curing water is provided to the concrete mixture. During the hydration of the cement paste within the concrete mixture, this internal curing water will be drawn from the LWA into the hydrating paste, maintaining a high degree of saturation (water-filled pores) in the cement paste and avoiding or at least reducing shrinkage stresses and their accompanying autogenous deformations [9] [6].

\section{Expermental work}

\subsection{Materials}

Limestone powder $\left(\mathrm{CaCO}_{3}\right)$ was used as a filler material and as percentage replacement of cement for producing SCC. The fineness (Blaine specific surface) of the used limestone powder (LSP) is $\left(200 \mathrm{~m}^{2} / \mathrm{kg}\right)$ and the chemical composition of LSP is given in Table (4).

Ordinary Portland Cement (O.P.C) (ASTM Type I). This cement complied with the Iraqi specification [16]. The coarse aggregate was brought from Al-Nibaii region with a nominal size of (14) $\mathrm{mm}$. Al-Ekhaider natural sand is used as fine aggregate in concrete mixes. Table (1) and Table (2) show the sieve analysis and properties for the sand used throughout this work. The grading and properties of the used sand and coarse aggregate satisfies the requirements of the [17].

Glenium 51 (G51) is used in this research as chemical admixture and complies with [5] type F.

Thermostone aggregate is considered as one type of lightweight aggregate and used in this study as internal curing material. Thermostone was gained from Karbala thermostone factory as waste and broken into smaller size particles like sand. Then, the crushed thermostone is washed and cleaned with water afterward dried by spread in air. The crushed particles are sieved and partially replaced by volume with the same size of sand with a certain percentage to have the same grading as the used sand which satisfies the grading requirements of the [17].

Later, the thermostone aggregate is soaked in water for (24) hours to bring the aggregate particles to saturated condition. Table (3) shows the physical properties of the used thermostone aggregate.

\subsection{Mix Design and Proportions}

The mix design method of the used SCC in this study is according to the European guidelines for SCC [12], and then the proportions of materials were modified after obtaining a satisfactory selfcompactability by evaluating through fresh concrete tests. The mix proportions of the SCC which was used throughout this research are shown in Table (5).

\subsection{Tests of Fresh Concrete}

Slump flow test, $T 50 \mathrm{~cm}$ test, $\mathrm{V}$ - funnel test and L-box test are used as test methods for workability properties of SCC. These methods are given in the European Federation dedicated to specialist construction chemicals and concrete systems SCC guidelines [12].

\subsection{Tests of Hardened Concrete}

Tests of hardened concrete in this research are shown below:

- Compressive strength test was conducted according to the British Standard [8] using (Tinius Olsen testing machine) compression device of $(1000 \mathrm{kN})$ maximum capacity. Three cubes $(100 * 100 * 100) \mathrm{mm}$ were tested for each mix at each age of $(7,28$ and 90$)$ days for the determination of compressive strength by using two sets of mixes for SCC, one of these sets is cured in water and the other is cured in air along the test period.

- Modulus of rupture test was performed on two $(100 \times 100 \times 400) \mathrm{mm}$ prisms according 
to [4] with span of (300) $\mathrm{mm}$ at age of (7, 28 and 90) days and the average of two specimens of each mix was adopted.

- Shrinkage test was conducted according to [3]. A micro - meter dial gauge with $(0.001) \mathrm{mm}$ reading accuracy was used in this test. Pins were fixed on prisms $(100 \times 100 \times 400) \mathrm{mm}$ after casting the specimens. The shrinkage test was conducted by using two sets of prisms specimens for SCC, the first set is cured for 7 days in water, after that it is taken out from water tank and left in air (laboratory conditions) for 21 days, the second set is cured in air along the test period for 28 days. The length change was calculated at age of $(7,14,21$ and 28$)$ days by using the following eq. (1):

$\mathrm{L}=\left[\left(\mathrm{L}_{\mathrm{x}}-\mathrm{L}_{\mathrm{i}}\right) / \mathrm{G}\right] \ldots \ldots(1)$

where:

$\mathrm{L}$ : Shrinkage strain at $(\mathrm{x})$ age.

$\mathrm{L}_{\mathrm{x}}$ : Comparator reading of specimen at $(\mathrm{x})$ age minus comparator reading of reference bar at $(\mathrm{x})$ age $(\mathrm{mm})$.

$\mathrm{L}_{\mathrm{i}}$ : Initial comparator reading of specimen minus reading of reference bar at that same time (mm).

G: Nominal gauge length ( $\mathrm{mm})$.

\section{Results and discussion}

\subsection{Test Results of Fresh Concrete}

The results of the slump flow test, V- funnel test and L-box test are shown in Table (6). These results indicate that in general, the workability of fresh SCC improves with increasing thermostone aggregate as partial sand replacement percentage as compared with reference concrete. This is due to that the pre-wetted fine lightweight aggregate (LWA), which provides a set of water-filled reservoirs within the concrete as additional moisture and in turn improves the workability of fresh SCC [13] [22]. These results are within the acceptable criteria for SCC [11] and also indicate excellent deformability and filling ability without any segregation, bleeding and blocking.

\subsection{Test Results of Hardened Concrete}

The results of the hardened properties which include (compressive strength, modulus of rupture and shrinkage) of SCC in this research are shown in Tables (7) to (12), and represented in Figures (1) to (6). From these results, it can be seen that internally cured SCC with thermostone aggregate has the best hardened properties which include (compressive strength, modulus of rupture) of externally cured SCC with both water and air as compared with reference concretes which didn't contain thermostone aggregate, as a result of internal curing technique. The highest increase in compressive strength reaches $16.72 \%$ and $12.67 \%$ for SCC internally cured with thermostone aggregate as partial sand replacement with percentage of $(5 \%)$ and cured in water and air, respectively.

In general, the results of shrinkage test have shown reduction in shrinkage of internally cured SCC with thermostone aggregate as compared with reference concretes which didn't contain LWA.

The increased strength may be due to increase in the degree of cement hydration as a result of internal curing water, which leads to increase the hydration products, improve the interfacial transition zone by filling internal voids of concrete, reduction of shrinkage induced micro cracking and decrease the porosity of SCC. This complies with studies carried out by [18] [10] [2].

\section{Conclusions}

Depending on the results of this investigation, the following conclusions can be drawn:

1. It is possible to produce self-compacting concrete (SCC) by using thermostone aggregate as partial sand replacement with three different percentages $(5 \%, 10 \%$ and $15 \%)$ by volume as internal curing material to internal curing technique.

2. It is possible to get benefit from the internal curing instead of traditional external curing because internal curing is easy to use and has a significant contribution to shrinkage reduction, enhancing durability, sustainability and hence, improving overall SCC performance.

3. Improving the workability and the hardened properties which include (compressive strength and modulus of rupture) of internally cured SCC with increasing thermostone aggregate as partial sand replacement as compared with reference concrete.

4. The SCC mixes are internally cured with thermostone aggregate and externally cured in both water and air exhibit very low shrinkage as compared with reference concrete.

\section{References}

[1] ACI Committee 213R-03, 2003, Guide for Structural Lightweight Aggregate Concrete, Reported by ACI committee 213, ACI Manual of Concrete Practice, pp. 213R-1-38.

[2] AL-Awadi, A.Y., 2013, M.Sc. Thesis, University of Baghdad.

[3] ASTM C490-00, 2000, Use of Apparatus for the Determination of Length Change of 
Hardened Cement Paste, Mortar, and Concrete, Annual Book of ASTM Standards C490 - 00.

[4] ASTM C293-02, 2002, Flexural Strength of Concrete (Using Simple Beam with Center Point Load), Annual Book of ASTM Standards C293-02, pp. 1-3.

[5] ASTM C494-05, 2005, Standard Specification for Chemical Admixtures for Concrete, Annual Book of ASTM Standards.

[6] Bentz, D.P., 2007, Internal Curing of HighPerformance Blended Cement Mortars, ACI Materials Journal, Vol. (104), No. (4), pp. 408414.

[7] Bouzoubaa, N., and Lachemi, M., 2001, SelfCompacting Concrete Incorporating HighVolumes of Class F Fly Ash: Preliminary Results, Cement and Concrete Research, Vol. 31, No.3, pp413-420.

[8] British Standards Institution. B.S 1881, Part 116, 1985, Method for Determination of Compressive Strength of Concrete Cubes.

[9] Cusson, D., and Hoogeveen, T., 2005, Nantes, France, pp. 579-584.

[10] Cusson, Z., and Lounis, L., 2010, .

[11]EFNARC, 2002, Specification and Guidelines for Self-Compacting Concrete, pp. 32, www.efranice.org.

[12] ERMCO, 2005, The European Guidelines for SCC, pp. 63, www.efca.info.

[13] Friggle, T., and Reeves, D., 2008, American Concrete Institute, Farmington Hills, MI, pp. 71-80.
[14] Holm, T.A., and Bremner, T.W., 2000, Engineer Research and Development Center, ERDC/SL TR-00-3, C.116, Vicksburg.

[15]Horta, A., 2005, M.Sc. Thesis, Georgia Institute of Technology, pp.228.

[16] Iraqi Specifications, IQS No.5, 1984, The Portland Cement, Central Apparatus for Standardization and Quality Control. (Translated from Arabic).

[17] Iraqi Specifications, IQS No.45, 1984, The Used Aggregate from Natural Sources in Concrete and Building, Central Apparatus for Standardization and Quality Control. (Translated from Arabic).

[18]Lura, P., 2003, Ph.D. thesis, Technical University of Delft.

[19] Lura, P., Bentz, D.P., Lange, D.A., Kovler, K., and Bentur, A., 2004, Proceeding International RILEM Symposium on Concrete Science and Engineering, Northwestern University, Evanston, Illinois. RILEM Publications S.A.R.L., pp. 137-151.

[20]Munaz, A.N., Bushra, I., and Rahman, S., 2011, BUET-Japan Institute of Disaster Prevention and Urban Safety, Bangladesh University of Engineering and Technology, Dhaka, Bangladesh, pp. 22-28.

[21] Selvamony, M.S., Ravikumar, S.U., and Basil, G., 2010,

[22] Villareal, V.H., 2008, Eds. D. Bentz and B. Mohr, American Concrete Institute, Farmington Hills, MI, pp. 45-56.

Table 1. Sieve analysis of sand and thermostone aggregate

\begin{tabular}{|c|c|c|}
\hline Sieve size $(\mathrm{mm})$ & Percent passing (\%) & I.Q.S.45: 1984 Limits Zone (2) \\
\hline 10 & 100 & 100 \\
\hline 4.75 & 99.8 & $70-100$ \\
\hline 2.36 & 84.4 & $55-90$ \\
\hline 1.18 & 65.6 & $35-59$ \\
\hline 0.60 & 41.8 & $8-30$ \\
\hline 0.30 & 11 & $0-10$ \\
\hline 0.15 & 2.2 & \\
\hline & Fineness modulus $=2.95$ & \\
\hline
\end{tabular}


Table (2): Physical and chemical properties of sand

\begin{tabular}{|c|c|c|}
\hline Property & Test result & I.Q.S.45: 1984 Limits \\
\hline \hline Apparent specific gravity & 2.55 & ---- \\
\hline \hline Absorption, $\%$ & 2.95 & ---- \\
\hline \hline Bulk density (kg/m3) & 1710 & $-0.50 \%(\max )$ \\
\hline \hline
\end{tabular}

Table (3): Physical properties of thermostone aggregate

\begin{tabular}{|c|c|}
\hline Property & Test result \\
\hline Shape & Crushed \\
\hline \hline Apparent specific gravity & 1.14 \\
\hline \hline Bulk density $\left(\mathrm{kg} / \mathrm{m}^{3}\right)$ & 675 \\
\hline Absorption, $\%$ & 48 \\
\hline
\end{tabular}

Table (4): Chemical composition of limestone powder

\begin{tabular}{|c|c|c|}
\hline No. & Constituents & Quantity (\%) \\
\hline 1 & $\mathrm{CaO}$ & 56.21 \\
\hline 2 & $\mathrm{SiO}_{2}$ & --- \\
\hline 3 & $\mathrm{Al} \mathrm{O}_{2}$ & ---- \\
\hline 4 & $\mathrm{Fe}_{2} \mathrm{O}_{3}$ & $\begin{array}{ll}--- \\
---\end{array}$ \\
\hline 5 & L.O.I & 43.78 \\
\hline 6 & $\mathrm{SO}_{3}$ & ---- \\
\hline 7 & $\mathrm{MgO}$ & ---- \\
\hline
\end{tabular}

Table (5): Mix proportions of SCC mixes*

\begin{tabular}{|c|c|c|c|c|c|c|c|}
\hline \multicolumn{3}{|c|}{$\begin{array}{c}\text { Thermostone } \\
\text { Aggregate (fine) } \\
\mathrm{kg} / \mathrm{m}^{3}\end{array}$} & \multirow[t]{2}{*}{$\begin{array}{c}\text { Coarse } \\
\text { Aggregate } \\
\mathrm{kg} / \mathrm{m}^{3}\end{array}$} & \multirow[t]{2}{*}{$\begin{array}{l}\text { Sand } \\
\mathrm{kg} / \mathrm{m}^{3}\end{array}$} & \multirow[t]{2}{*}{$\begin{array}{c}\text { Limestone } \\
\text { Powder } \\
(5 \%) \mathrm{kg} / \mathrm{m}^{3}\end{array}$} & \multirow[t]{2}{*}{$\begin{array}{l}\text { Cement } \\
\mathrm{kg} / \mathrm{m}^{3}\end{array}$} & \multirow[t]{2}{*}{ Index of Mixes } \\
\hline $15 \%$ & $10 \%$ & $5 \%$ & & & & & \\
\hline$\overline{----}$ & $\overline{----}$ & $\overline{-\overline{---}}$ & $\overline{850}$ & 825 & 25 & $\overline{475}$ & Mix-R \\
\hline--- & --- & 16.3 & 850 & 783.75 & 25 & 475 & Mix-T5\% \\
\hline--- & 32.6 & --- & 850 & 742.5 & 25 & 475 & Mix-T10\% \\
\hline 48.9 & --- & $\begin{array}{l}--- \\
--\end{array}$ & 850 & 701.25 & 25 & 475 & Mix-T15\% \\
\hline
\end{tabular}


*Water $\left(\mathrm{kg} / \mathrm{m}^{3}\right)=185$

Glenium 51 (liter per $100 \mathrm{~kg}$ of cementitious materials) $=1.1$

Table (6): The results of the slump flow test, V-funnel test and L-box test

\begin{tabular}{|c|c|c|c|}
\hline \multirow{2}{*}{ Mixes } & \multicolumn{2}{|c|}{ Compressive strength $(\mathrm{MPa})$} \\
\cline { 2 - 4 } & 7 days & 28 days & 90 days \\
\hline \hline Mix-R & 40.76 & 42.88 & 45.71 \\
\hline \hline Mix-T5\% & 44.04 & 53.35 \\
\hline \hline Mix-T10\% & 47.66 & 50.82 \\
\hline \hline Mix-T15\% & 45.98 & 42.04 \\
\hline
\end{tabular}

Table (7): Test results of compressive strength of SCC internally cured with thermostone aggregate and externally cured with water

\begin{tabular}{|c|c|c|c|c|c|c|}
\hline \multirow{2}{*}{$\begin{array}{l}\text { Index of } \\
\text { Mixes }\end{array}$} & \multicolumn{2}{|c|}{ Slump flow } & \multicolumn{2}{|c|}{ V-Funnel } & \multicolumn{2}{|c|}{ L-Box } \\
\hline & $\overline{\mathrm{D}(\mathrm{mm})}$ & $\overline{\mathrm{T}} 50 \mathrm{~cm}(\mathrm{sec})$ & TV (sec) & TV5min (sec) & $\begin{array}{c}\text { Blocking } \\
\text { Ratio }(\mathrm{H} 2 / \mathrm{H} 1) \\
\end{array}$ & $\overline{\mathrm{T} 40 \mathrm{~cm}(\mathrm{sec})}$ \\
\hline Mix-R & 736 & 3.5 & 10 & 12 & 0.9 & 3.5 \\
\hline Mix-T5\% & 747 & 3.3 & 9.5 & 11.6 & 0.91 & 3.4 \\
\hline Mix-T10\% & $\overline{760}$ & 3.1 & 8.5 & 10.5 & 0.92 & 3.2 \\
\hline Mix-T15\% & $\overline{772}$ & 2.8 & 7.2 & 9.3 & $\overline{0.93}$ & 3 \\
\hline & & & & & & \\
\hline
\end{tabular}

Table (8): Test results of compressive strength of SCC internally cured with thermostone aggregate and externally cured with air

\begin{tabular}{|c|c|c|c|}
\hline \multirow[t]{2}{*}{ Mixes } & \multicolumn{3}{|c|}{ Compressive strength (MPa) } \\
\hline & 7 days & 28 days & 90 days \\
\hline Mix-R & 38.27 & 40.22 & 42.63 \\
\hline Mix-T5\% & 40.21 & 43.48 & 48.03 \\
\hline Mix-T10\% & 38.96 & 41.92 & 45.95 \\
\hline Mix-T15\% & 35.13 & 37.83 & 40.89 \\
\hline
\end{tabular}

Table (9): Test results of modulus of rupture of SCC internally cured with thermostone aggregate and externally cured with water

\begin{tabular}{|c|c|c|c|}
\hline \multirow[t]{2}{*}{ Mixes } & \multicolumn{3}{|c|}{ Modulus of rupture (MPa) } \\
\hline & 7 days & 28 days & 90 days \\
\hline Mix-R & 5.66 & 5.87 & 6.04 \\
\hline Mix-T5\% & 5.98 & 6.31 & 6.65 \\
\hline Mix-T10\% & 5.80 & 6.04 & 6.28 \\
\hline Mix-T15\% & 5.63 & 5.75 & 5.88 \\
\hline
\end{tabular}


Table (10): Test results of modulus of rupture of SCC internally cured with thermostone aggregate and externally cured with air

\begin{tabular}{|c|c|c|c|}
\hline \multirow[t]{2}{*}{ Mixes } & \multicolumn{3}{|c|}{ Modulus of rupture (MPa) } \\
\hline & 7 days & 28 days & 90 days \\
\hline Mix-R & 5.32 & 5.51 & 5.65 \\
\hline Mix-T5\% & 5.57 & 5.85 & 6.07 \\
\hline Mix-T10\% & 5.45 & 5.66 & 5.86 \\
\hline Mix-T15\% & 5.31 & 5.43 & 5.52 \\
\hline
\end{tabular}

Table (11): Test results of volume change of SCC internally cured with thermostone aggregate and externally cured with water for 7 days and with air until 21 days

\begin{tabular}{|c|c|c|c|c|c|c|}
\hline \multirow[t]{3}{*}{ Mixes } & \multicolumn{6}{|c|}{ 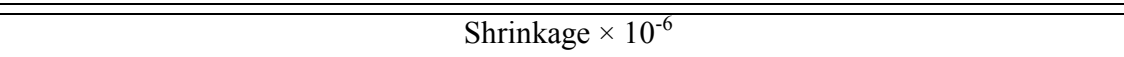 } \\
\hline & \multicolumn{3}{|c|}{ Water curing } & \multicolumn{3}{|c|}{ Air curing } \\
\hline & 1 day & 4 days & 7 days & 14 days & 21 days & 28 days \\
\hline Mix-R & 0 & +20 & +25 & -40 & -135 & -180 \\
\hline Mix-T5\% & $\overline{0}$ & +30 & +35 & -30 & $\overline{-40}$ & 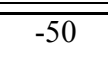 \\
\hline$\overline{\overline{M i x}-\mathrm{T} 10 \%}$ & $\overline{0}$ & $\overline{+35}$ & 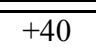 & $\overline{-20}$ & $\overline{-30}$ & $\overline{-35}$ \\
\hline Mix-T15\% & 0 & +40 & +50 & -5 & -10 & -15 \\
\hline
\end{tabular}

Table (12): Test results of volume change of SCC internally cured with thermostone aggregate and externally cured with air until 28 days

\begin{tabular}{|c|c|c|c|c|c|c|}
\hline \multirow[t]{3}{*}{ Mixes } & \multicolumn{6}{|c|}{ Shrinkage $\times 10^{-6}$} \\
\hline & \multicolumn{6}{|c|}{ Air curing } \\
\hline & 1 day & $\overline{4} 4$ days & 7 days & 14 days & 21 days & 28 days \\
\hline$\overline{\text { Mix-R }}$ & $\overline{0}$ & $\overline{-105}$ & $\overline{-190}$ & $\overline{-220}$ & -240 & -255 \\
\hline Mix-T5\% & $\overline{0}$ & $\overline{-25}$ & $\overline{-50}$ & -65 & $\overline{-75}$ & -85 \\
\hline Mix-T10\% & $\overline{0}$ & $\overline{-15}$ & $\overline{-30}$ & -45 & $\overline{-50}$ & $\overline{-65}$ \\
\hline Mix-T15\% & $\overline{0}$ & -10 & -20 & -35 & -40 & $\overline{-50}$ \\
\hline
\end{tabular}




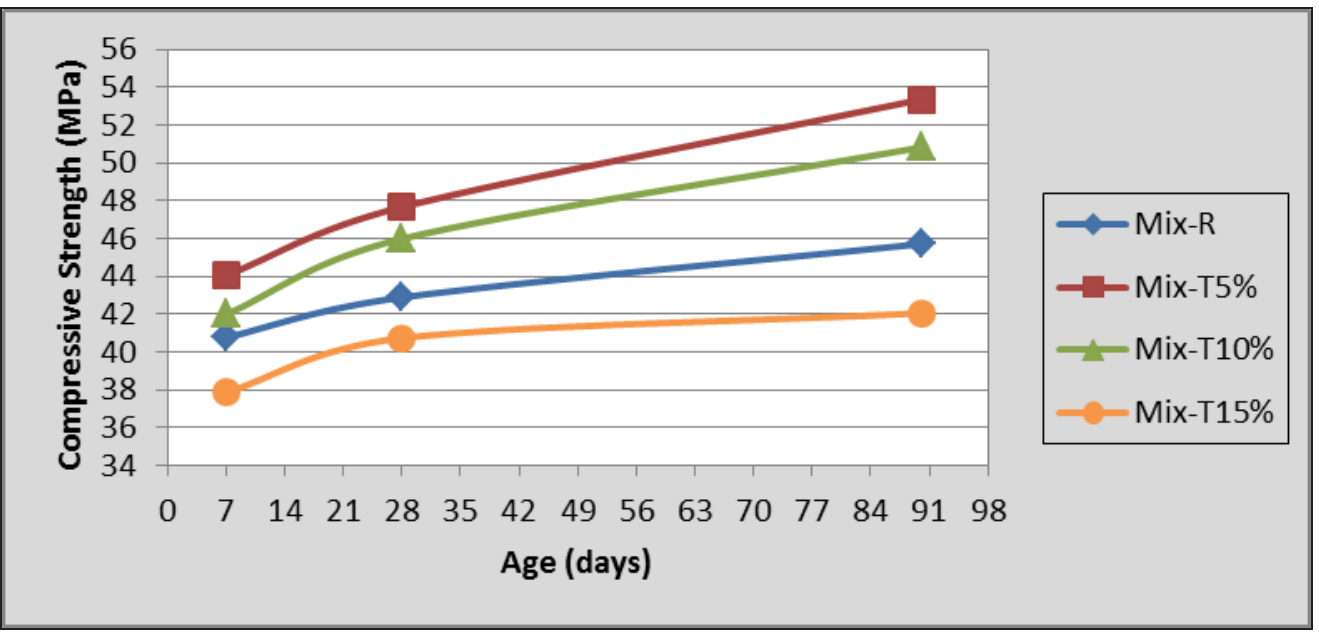

Figure (1): Compressive strength development of SCC internally cured with thermostone aggregate and externally cured with water

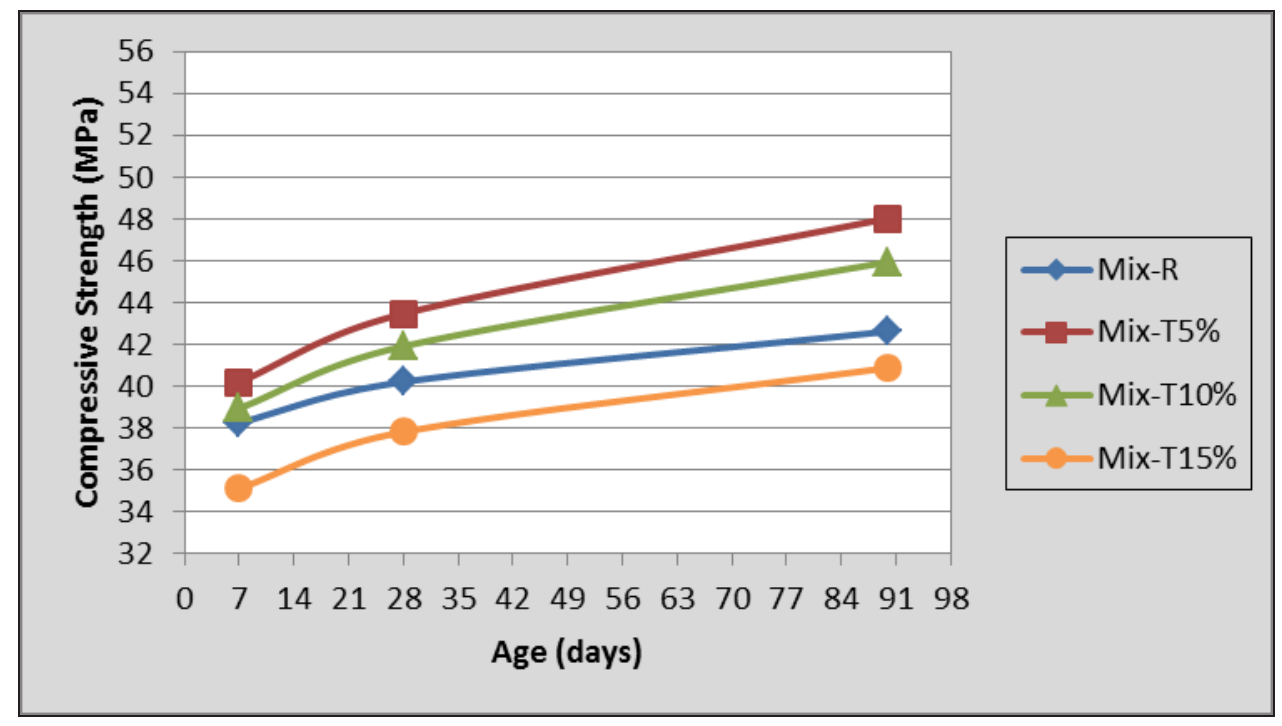

Figure (2): Compressive strength development of SCC internally cured with thermostone aggregate and externally cured with air 


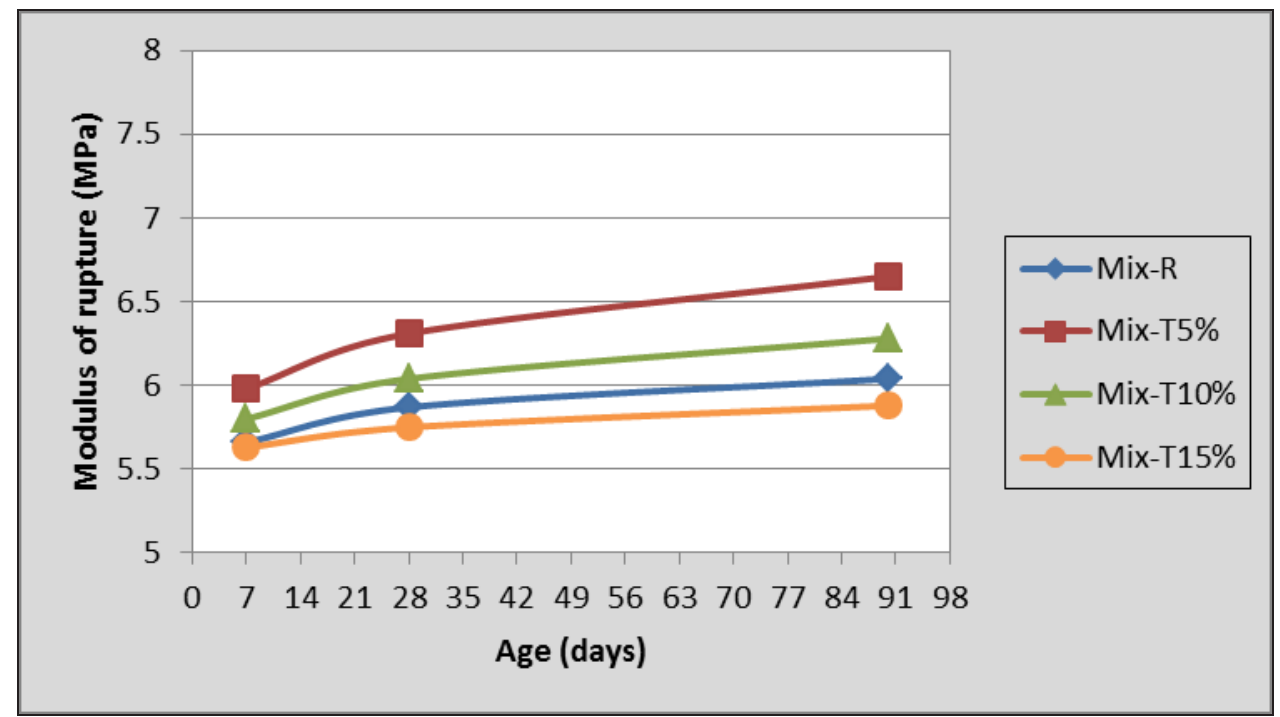

Figure (3): Modulus of rupture development of SCC internally cured with thermostone aggregate and externally cured with water

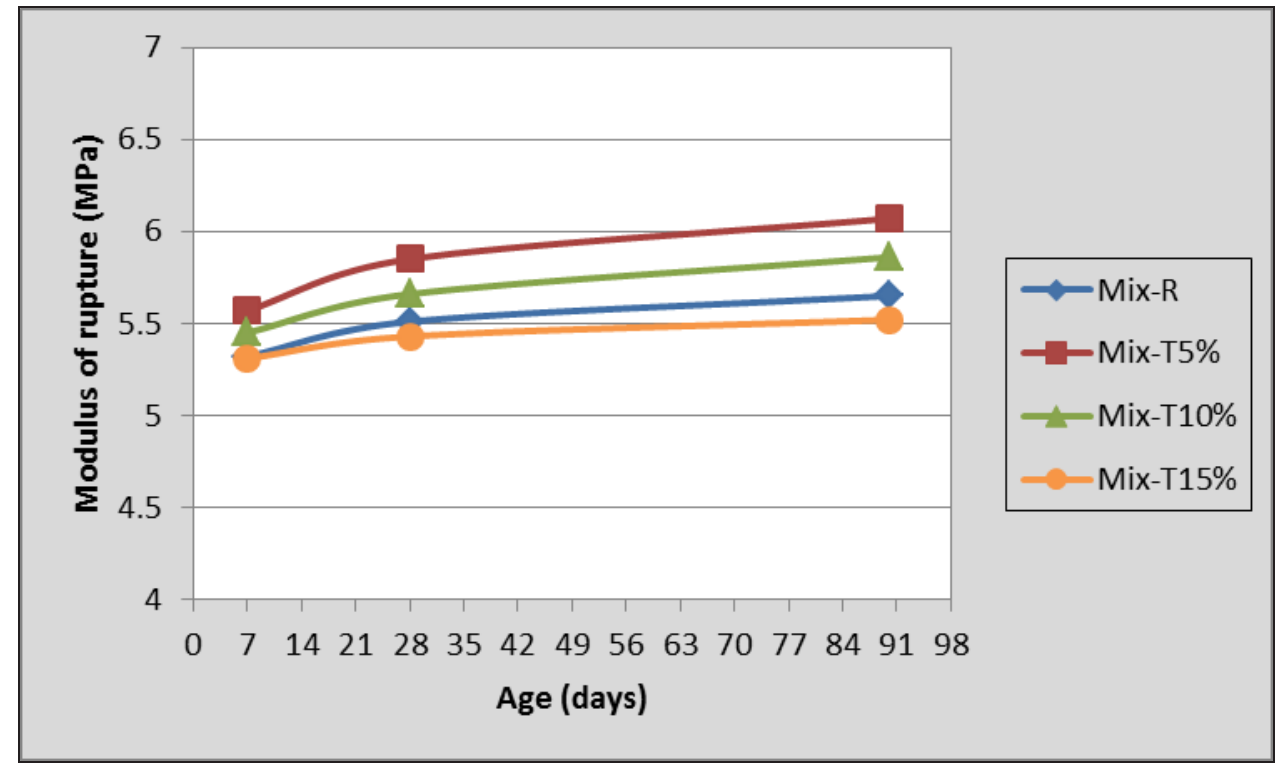

Figure (4): Modulus of rupture development of SCC internally cured with thermostone aggregate and externally cured with air 


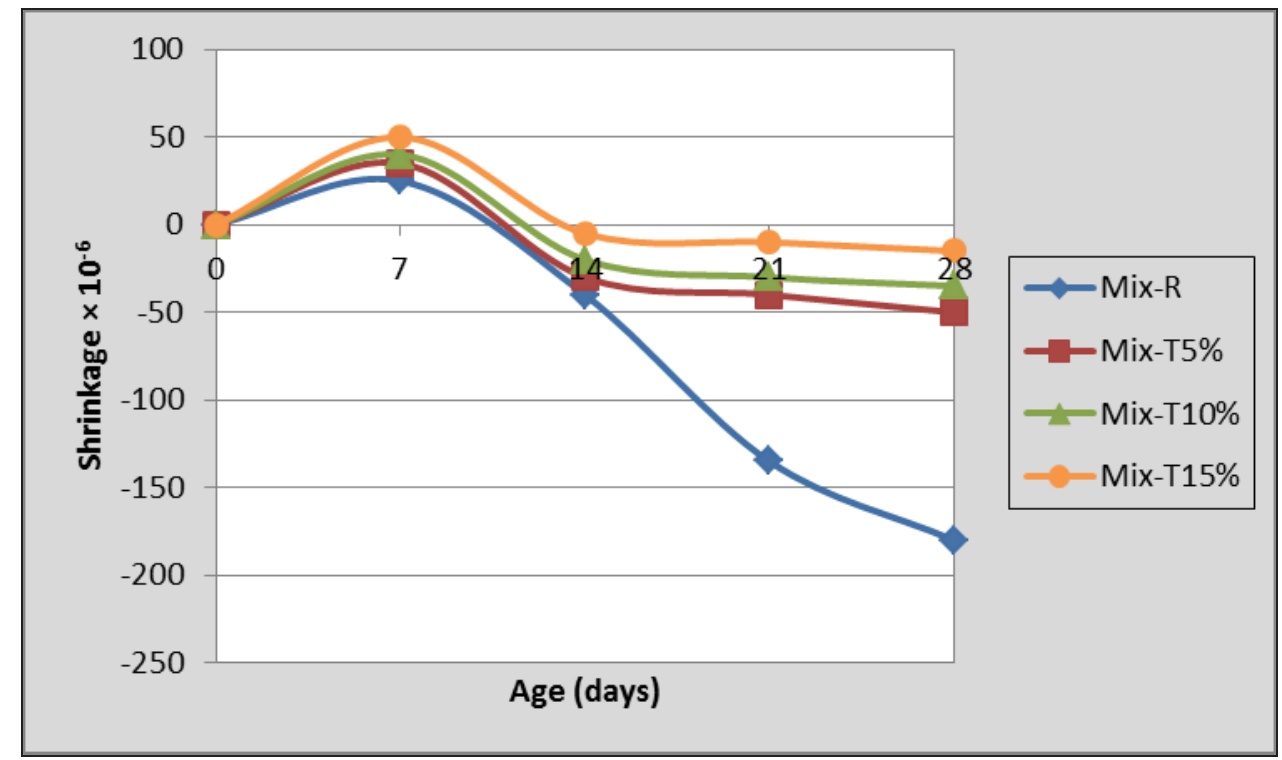

Figure (5): Volume change development of SCC internally cured with thermostone aggregate and externally cured with water for 7 days and with air until 21 days

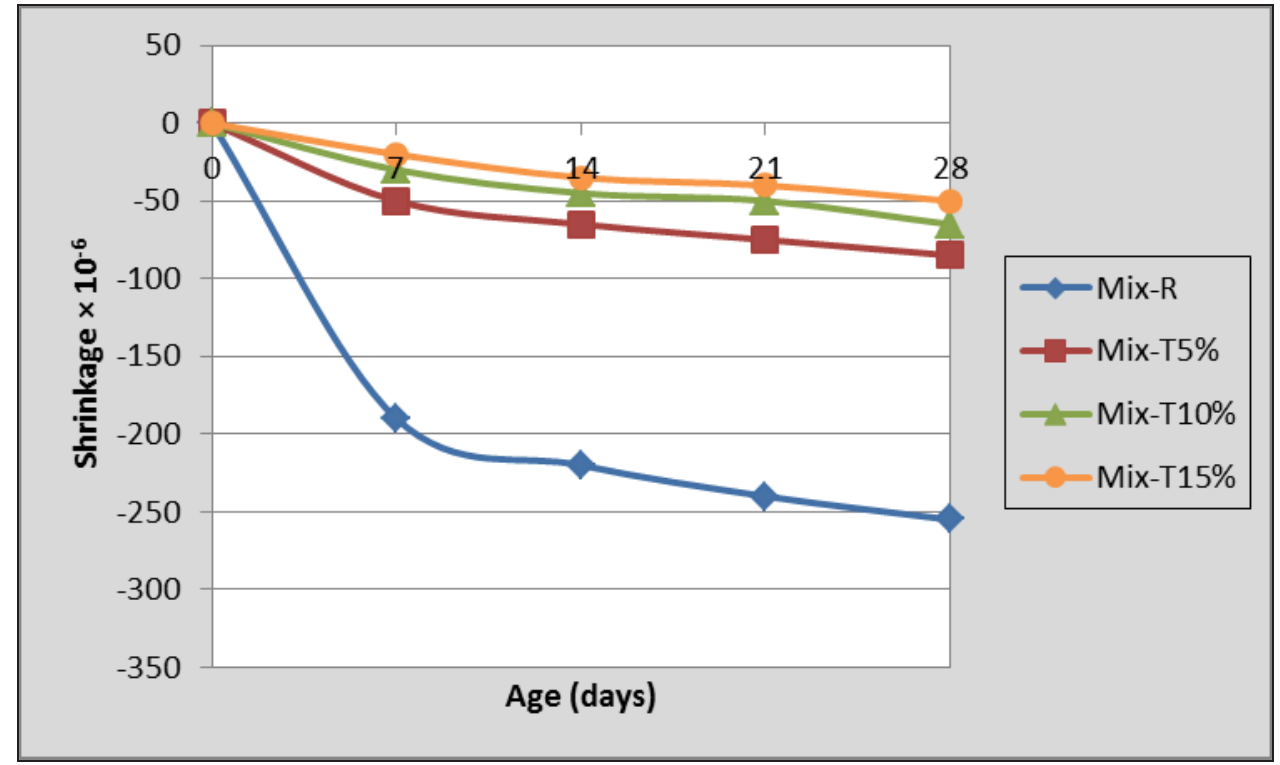

Figure (6): Volume change development of SCC internally cured with thermostone aggregate and externally cured with air until 28 days 